\title{
Attitude of rural youth towards agriculture as a means of livelihood
}

\author{
Renu Gangwar* and V.L.V. Kameswari \\ Department of Agricultural Communication, Govind Ballabh Pant University of Agriculture and Technology, \\ Pantnagar- 263145 (Uttarakhand), INDIA \\ "Corresponding author. E-Mail: renoogangwar@gmail.com
}

Received: August 30, 2015; Revised received: March 4, 2016; Accepted: May 27, 2016

\begin{abstract}
The importance of agriculture to the socio-economic development of the country cannot be overemphasized. Agriculture sector is potentially the largest employment providing sector in the country. Despite this, unemployment is high among rural youth, who prefer to migrate to urban areas to take up low paying jobs. The present study was carried out mainly to find out the characteristics of rural youth and their attitude towards agriculture as a means of livelihood. The study was conducted in four villages in Udham Singh Nagar district in Uttarakhand. Data was collected from 115 youth using pretested interview schedule. It was found that maximum number of respondents $(31.30 \%)$ had education up to higher secondary level, majority were students $(46.96 \%)$ and had medium level of mass media exposure $(72.17 \%)$ and change proneness $(58.30 \%)$. The study indicates that majority $(85.20 \%)$ of the respondents had neutral attitude towards agriculture followed by 13.90 percent of the respondents who had negative attitude towards agriculture and only $0.90 \%$ respondents had positive attitude towards agriculture. The study indicates that the findings will help extension policy makers to frame appropriate training programmes for educating youth regarding opportunities in agriculture and allied sectors.
\end{abstract}

Keywords: Agriculture, Attitude, Livelihood, Rural Youth, Unemployment

\section{INTRODUCTION}

Global population of youth reached one billion marks in 2000 and this increased to 1.2 billion in 2011. Out of these, 754 million ( $85 \%$ ) live in developing countries and approximately $60 \%$ live in Asia alone. The youth population growth rate is generally higher in the poor countries and their number has tripled since 1950s. By the year 2025, the number of youth living in developing countries is likely to reach $89.5 \%$. In view of their significance, the United Nations has declared 2011 as the 'International Year of Youth' (World Youth Report, 2012). Youth employment: Youth perspectives on the pursuit of decent work in changing times. New York: United Nations Department of Economic and Social Affairs). Rural youth account for around $55 \%$ of the total world youth population. They are also among the most disadvantaged groups in the society and have limited access to educational programs. Involvement of youth in agriculture is necessary for overall development of low income nation as well as youth in these nations in particular. Their active participation in agriculture is possible only if they have requisite skills, information and a positive attitude towards agriculture. A favorable attitude is one of the important prerequisites for the willingness to participate in agriculture and choosing agriculture as a career (GI, 2012). In India, about $70 \%$ population is below the age of 35 years, making it the youngest nation in the World. According to some esti- mates, the proportion of population under 25 years in India is $51 \%$. Some experts refer to this large proportion of youth as "demographic dividend" because greater proportion of the population is young and in the working age-group which can lead to economic growth. However, out of the youth population of 460 million, only 333 million youth in India are literate and unemployment rate is highest $(10.6 \%)$ among youth. By 2020, the average Indian will be only 29 year old, whereas in China and the United States of America the average age is estimated to be 37 years. This high percentage of youth can be utilized for taking Indian agriculture to new heights by channelizing the creative energies of the youth through development of appropriate skills, knowledge and attitude. This predominance of youth in the population is expected to last until 2050. Hence, the National Youth Policy (2012) emphasizes youth empowerment in different spheres of national life. There are several advantages of involvement of youth in agriculture as they have the latent energy, capacity and ability to produce, propensity to learn and grasp new ideas or technologies faster and they are excellent source of ideas and innovations (Government of India, Top of National Youth Policy, 2012). According to Swaminathan, M.S. (2007), Migration of young people to urban areas in search of job has reduced the availability of human resources for agricultural activities. Tackling factors that negate interest of youth in agriculture will ensure improvement 
in agricultural production, which is essential for food security of the nation. If agriculture is profitable, then it can serve as a source of gainful employment for the youth. This will go a long way in solving the problem of migration of youth arising from under or disguised unemployment in agriculture sector. Involvement of youth in agriculture is essential as they not only contribute to the labour force but also bring fresh ideas and skills and adopt innovations more easily. Hence, it is important to know the attitude of rural youth regarding agriculture as livelihood option and their awareness level.. In view of the above, objective of the study is to find out the attitude of youth towards agriculture as a means of livelihood. This will help in formulation of suitable policies, providing incentives and opportunities and designing educational training programme that can help in attracting youth in agriculture. (Swaminathan, M.S. 2007). Agriculture Can not Wait: New Horizons in Indian Agriculture, Academic Foundation, National Academy of Agricultural Sciences).

\section{MATERIALS AND METHODS}

The study was conducted in two blocks (Kichha and Sitarganj) of Udham Singh Nagar district of Uttarakhand state. The blocks were selected purposively because these blocks have maximum population as well as maximum cultivable land in the district Udham Singh Nagar. Two villages from each block (Ajeetpur and Bara from Kichha block and Sisaiya and Barri from Sitarganj block) were selected purposively as these villages have large population. Total 115 respondents were selected through simple random sampling, the respondents belonging from age group of 15-24 years, owning agricultural land and residing permanently in the village. Data collection was done by using pretested structured interview schedule. (Kothari, C.R. 1990). Research methology: Methods and Techniques. New Age International, Delhi). After going through various theories as career choice, education, present employment status, family size, family type, marital status, caste, occupation of head of the household, main source of income of family, size of the land holding, total family income, number of family members involved in agriculture, media ownership, mass media exposure, extension contact, cosmopoliteness, achievement motivation and change proneness were taken as independent variables in the present study. Attitude of rural youth towards agriculture as a means of livelihood was taken as the dependent variable.

\section{RESULTS AND DISCUSSION}

Sample characteristics: Majority of the youth $(97.40$ $\%$ ) were literate and maximum number of respondents $(31.30 \%)$ had educational qualification up to higher secondary level. It indicates that youth and their families were aware of the importance of education as well as its role in their future development. Majority of the respondents were students $(46.96 \%$ ) and $22.91 \%$ of the respondents were unemployed. This figure is higher than the national figure of unemployed youth. Majority of the respondents belonged to medium size family $(68.7 \%)$ and joint family (54.79\%) A vast majority of the respondents $(86.08 \%)$ were unmarried, this high percentage of unmarried youth is due to delay in age of marriage even in rural areas because of economic, socio cultural and legal reasons. Further, it was found that majority of the households relied on agriculture $(68.70 \%)$ as a means of livelihood and $53 \%$ had land up to one acre only. Majority of the respondents belonged from APL family $(71.30 \%)$ and had medium level of mass media exposure $(72.17 \%)$. It was observed that most of the school going youth were using mobile phones for various purposes. Television and newspaper were the other frequently used media whereas reach of computer and landline phone was limited to few households. Most of the respondents have medium level of cosmopoliteness $(73.10 \%)$ and extension agency contact $(76.52 \%)$. Hence, it can be concluded that the government and private extension agencies rarely visit these villages. It was also found that majority of the youth have medium level of change proneness $(58.30 \%)$ and achievement motivation (70 \%) which indicates that they do not have a high urge to do things solely for their own satisfaction or to prove their worth (Table 1).

Attitude of youth towards agriculture as a means of livelihood: Attitude of youth towards agriculture was divided into five categories; viz. very negative, negative, neutral, positive and very positive. Data regarding attitude of youth towards agriculture as a means of livelihood has been presented in the Table 2. It can be seen that a vast majority of youth $(85.20 \%)$ in the study area have a neutral attitude towards agriculture as a means of livelihood. This is followed by $13.90 \%$ of the youth, who have negative attitude towards agriculture as a means of livelihood and only $0.90 \%$ youth have positive attitude towards agriculture. None of the respondents had highly positive and highly negative attitude towards agriculture as a means of livelihood. These findings confirm earlier studies (Faralu, 2003; Ghadiri, 2005; Juma, 2007; and Norsida, 2007) which indicate that there is a negative attitude among youth towards agriculture. However, the percentage of youth with a negative attitude towards agriculture in the current study was found to be less than that reported in other studies (Russell, 1993; Annamalai, 1994: Prasad, 2002 and Sajjan, 2012). The present study, however, contradicts the findings from some studies (Hosenally, 2012; Movahedi, 2013) where it was found that majority of the youth had a positive attitude towards agriculture (Table 2). Negative attitude of about $14 \%$ of the youth towards agriculture when read along with the data on number of youth with lack of youth positive attitude is a worrisome fact. This indicates towards a serious human re source crisis in the agriculture sector in the years to come. This problem will be compounded by the ab- 
Table 1. Characteristics of the rural youth.

\begin{tabular}{|c|c|c|c|}
\hline S. N. & Variables & Frequency & Percentage \\
\hline \multirow[t]{4}{*}{1.} & Age & & \\
\hline & Very young (up to 17 years) & 24 & 20.87 \\
\hline & Young (18-23 years) & 77 & 66.96 \\
\hline & Mature (above 23 years) & 14 & 12.17 \\
\hline \multirow[t]{11}{*}{2.} & Education & & \\
\hline & Illiterate & 3 & 2.60 \\
\hline & Can read only & 0 & 0 \\
\hline & Can write only & 0 & 0 \\
\hline & Can read and write & 0 & 0 \\
\hline & Primary education & 10 & 8.70 \\
\hline & Secondary education & 27 & 23.48 \\
\hline & Higher secondary education & 36 & 31.30 \\
\hline & Diploma & 10 & 8.70 \\
\hline & Graduate & 27 & 23.48 \\
\hline & Post graduation & 2 & 1.74 \\
\hline \multirow[t]{5}{*}{3.} & Present employment status & & \\
\hline & Employed & 22 & 19.54 \\
\hline & Unemployed & 26 & 22.91 \\
\hline & Student & 54 & 46.96 \\
\hline & Farmer & 12 & 10.59 \\
\hline \multirow[t]{4}{*}{4.} & Family size & & \\
\hline & Small ( up to 4) & 23 & 20 \\
\hline & Medium (5-8) & 79 & 68.70 \\
\hline & Large (above 8) & 13 & 11.30 \\
\hline \multirow[t]{4}{*}{5.} & Family type & & \\
\hline & Nuclear & 46 & 40 \\
\hline & Joint & 63 & 54.79 \\
\hline & Extended & 6 & 5.21 \\
\hline \multirow[t]{3}{*}{6.} & Marital status & & \\
\hline & Unmarried & 99 & 86.08 \\
\hline & Married & 16 & 13.92 \\
\hline \multirow[t]{4}{*}{7.} & Caste & & \\
\hline & General caste & 21 & 19.50 \\
\hline & Other backward caste & 74 & 64.50 \\
\hline & Schedule caste and Schedule tribes & 18 & 16 \\
\hline \multirow[t]{7}{*}{8.} & Occupation of head of the household & & \\
\hline & Labour & 10 & 8.70 \\
\hline & Caste occupation & 3 & 2.60 \\
\hline & Business & 12 & 10.44 \\
\hline & Independent profession & 0 & 0 \\
\hline & Cultivation/farming & 79 & 68.70 \\
\hline & Service & 11 & 9.56 \\
\hline \multirow[t]{6}{*}{9.} & Main source of income of family & & \\
\hline & Labour & 9 & 7.90 \\
\hline & Caste occupation & 4 & 3.50 \\
\hline & Business & 13 & 11.20 \\
\hline & Farming & 79 & 68.70 \\
\hline & Service & 10 & 8.70 \\
\hline \multirow[t]{5}{*}{10.} & Size of land holding & & \\
\hline & Up to 1 acre & 61 & 53 \\
\hline & Up to 5 acres & 36 & 31.30 \\
\hline & Up to10 acres & 10 & 8.70 \\
\hline & Up to 15 acres & 8 & 7 \\
\hline \multirow[t]{3}{*}{11.} & Total family income & & \\
\hline & APL (more than Rs. 27,000 p.a) & 82 & 71.30 \\
\hline & BPL (less than Rs. 27,000 p.a) & 33 & 28.70 \\
\hline \multirow[t]{4}{*}{12.} & Media ownership & & \\
\hline & Low (up to 1) & 12 & 10.40 \\
\hline & Medium (2-3) & 98 & 85.20 \\
\hline & High (above 3 ) & 5 & 4.40 \\
\hline \multirow[t]{4}{*}{13.} & Mass media exposure & & \\
\hline & Low & 15 & 13.05 \\
\hline & Medium & 83 & 72.17 \\
\hline & High & 17 & 14.88 \\
\hline 14. & Extension contact & & \\
\hline & Low (up to 1) & 19 & 16.53 \\
\hline & Medium (2-5) & 88 & 76.52 \\
\hline & $\operatorname{High}(6-9)$ & 8 & 6.95 \\
\hline
\end{tabular}




\begin{tabular}{|c|c|c|c|}
\hline \multirow[t]{4}{*}{15.} & \multicolumn{3}{|c|}{ Cosmopoliteness } \\
\hline & \multicolumn{3}{|c|}{ Low } \\
\hline & \multicolumn{3}{|l|}{ Medium } \\
\hline & \multicolumn{3}{|c|}{ High } \\
\hline \multirow[t]{4}{*}{16.} & \multirow{2}{*}{\multicolumn{3}{|c|}{$\begin{array}{l}\text { Achievement motivation } \\
\text { Low }\end{array}$}} \\
\hline & & & \\
\hline & \multicolumn{3}{|c|}{ Medium } \\
\hline & \multicolumn{3}{|c|}{ High } \\
\hline \multirow[t]{4}{*}{17.} & \multicolumn{3}{|c|}{ Change proneness } \\
\hline & \multicolumn{3}{|c|}{ Low } \\
\hline & \multicolumn{3}{|l|}{$\begin{array}{l}\text { Medium } \\
\text { High }\end{array}$} \\
\hline & \multicolumn{3}{|l|}{ High } \\
\hline \multicolumn{4}{|c|}{$\begin{array}{l}\text { Table 2. Attitude of rural youth towards agriculture as a } \\
\text { means of livelihood. }\end{array}$} \\
\hline S. N. & Category & Number & Percentage \\
\hline 1 & Very negative & 0 & 0 \\
\hline 2 & Negative & 16 & 13.90 \\
\hline 3 & Neutral & 98 & 85.20 \\
\hline 4 & Positive & 1 & 0.90 \\
\hline 5 & Very positive & 0 & 0 \\
\hline
\end{tabular}

sence of innovative ideas and energy that youth can bring to any sector. The negative attitude of youth is due to several factors like lack of awareness about opportunities in the sector, lack of incentives, high risks involved due to natural hazards and absence of policy measures, etc. In addition, land fragmentation resulting in increase in number of marginal and small holdings and low returns from the sector also play a critical role in formation of negative attitude towards agriculture among rural youth. These constraints have to be addressed if the nation wants to retain youth in agriculture in future. At the same time, the study also indicates a large percentage of youth with neutral attitude towards agriculture as a source of livelihood. If the existing constraints are removed/ overcome, it is likely that some of the youth with neural attitude may proactively choose agriculture as a livelihood option.

\section{Conclusion}

The government has emphasized the need to involve youth in agriculture and has accordingly framed several policies. Majority $(85.20 \%)$ of the respondents had neutral attitude towards agriculture as a means of livelihood followed by $13.90 \%$ of the respondents who had negative attitude and only $0.90 \%$ respondents had positive attitude towards agriculture as a means of livelihood. A positive attitude towards agriculture is a prerequisite for their engagement in the sector. The neutral attitude towards agriculture as a means of livelihood indicates that youth were quite aware about career opportunities in agriculture. Hence, there is a need to make special efforts to reach and convince the rural youth regarding the need and advantage of taking up agriculture.

\section{REFERENCES}

Annamalai, R., Leticemary, M. and Muttaiah, (1994). Attitude of farm youth towards agriculture. Journal of Extension Education, 5 (4): 978979.

Faralu, M.R. (2003). Attitude of youth towards agriculture as a career among students of basic vocational agriculture training centres. The ses, M.sc. Ahmadu Bello University, Zaria, Nigeria.

Ghadiri, M. (2005). Effective factors of rural youth a t $\mathrm{t} i \mathrm{t} \mathrm{u} \mathrm{d} \mathrm{e}$ about employment in agricultural activities. Unpublished research paper, Department of Rural Development, Science and Research Branch. Iran.

GI (2012). Government of India (GI),Ministry of youth affairs and sports. Draft national youth policy.

Hosenally, N. (2012). Current and emerging youth policies and initiatives with a special focus on links to agriculture: A case study. Food, Agriculture and Natural Resources Policy Analysis Network. South Africa.

Juma, A. (2007). Promoting livelihood opportunitiesfor rural youth. Paper for IFAD Governing Council Roundtable: Generating remunerative livelihood opportunities for rural youth. Tanzania.

Kothari, C.R. (1990). Research methology: Methods and Techniques. New Age International, Delhi.

Movahedi, R., Latifi, S. and Sayyar, L.Z. (2013). Th factors affecting agricultural students' attitude towards selfemployment and entrepreneurship. International Journal of Agriculture and Crop Sciences, 5 (16): 1813-1819.

Norsida, M. (2007). The agricultural community Transformational issues, challenges and drection for youth. Economic Planning Unit and Ministry of Human Resources. Malasia. 128-144.

Prasad, C. (2002). Youth development education, aims and scope. Journal of Extension Education. 11 (1): 4-5.

Russell, E.B., Remmers, H.H. and Raphael N.E. (1993). Attracting youth to agriculture: How colleges of agriculture can expand their role. Journal of Extension., 31 (4): $13-14$

Sajjan, S.P., Manjunath, M. and Halakatti, S.B. (2012). A study on the attitude of rural youth towards agriculture. Research Journal of Agricultural Sciences, 9 (2): 131-136.

Swaminathan, M.S. (2007). Agriculture Can not Wait: New Horizons in Indian Agriculture, Acdemic Foundation, National Academy of Agricultural Sciences.

World Youth Report. (2012). Youth employment: Youth perspectives on the pursuit of decent work in changing times. New York: United Nations Department of Economic and Social Affairs. 